\title{
The economic impact of tourism in six German national parks
}

\author{
Marius Mayer $^{\mathrm{a}, *}$, Martin Müller ${ }^{\mathrm{b}}$, Manuel Woltering ${ }^{\mathrm{a}}$, Julius Arnegger ${ }^{\mathrm{a}}$, Hubert Job ${ }^{\mathrm{a}}$ \\ a Institute of Geography, Julius-Maximilians-Universität Würzburg, Am Hubland, 97074 Würzburg, Germany ${ }^{1}$ \\ ${ }^{\mathrm{b}}$ School of Humanities and Social Sciences, Universität St. Gallen, Gatterstr. 1, 9000 St. Gallen, Switzerland ${ }^{2}$
}

\section{A R T I C L E I N F O}

\section{Article history:}

Received 20 July 2009

Received in revised form 12 April 2010

Accepted 25 April 2010

Available online 23 May 2010

\section{Keywords:}

National parks

Protected areas

Germany

Tourism

Economic impacts

\begin{abstract}
A B S T R A C T
Tourism in protected areas can create considerable income for adjacent communities. Based on faceto-face visitor surveys, the present study measures the structure, size and economic impact of tourist expenditure in the six German national parks Niedersächsisches Wattenmeer, Bayerischer Wald, Eifel, Müritz, Hainich and Kellerwald-Edersee. We find that mean daily expenditure per person of national park visitors is considerably below the national averages for tourists in Germany: day-trippers spend between EUR 7 and 13 per day (national average: EUR 28), whereas overnight visitors spend between EUR 37 and 57 (national average: EUR 120). The proportion of visitors with high national park affinity varies between a maximum of almost $46 \%$ in Bayerischer Wald and a minimum of nearly $11 \%$ in Niedersächsisches Wattenmeer. Between $49 \%$ and $51 \%$ of tourist expenditure is captured as direct and indirect income. The total impact of tourism ranges between EUR 525 million in Niedersächsisches Wattenmeer and EUR 1.9 million in Kellerwald-Edersee, reflecting the national parks' distinct trajectories as tourist destinations. In order to increase the economic benefits accruing from national parks regional policy could aim at a qualitative upgrading of tourist services, increased marketing of the unique national park label and the promotion of a diverse regional supply base.
\end{abstract}

(c) 2010 Elsevier B.V. All rights reserved.

\section{Introduction}

For national parks, the 2007 guidelines of the International Union for the Conservation of Nature (IUCN) stipulate both the protection of the ecological integrity of ecosystems and opportunities for recreation and tourism as primary goals (IUCN, 2008). Given this double mandate of use and protection, national parks have the potential and perhaps even the obligation to actively promote sustainable rural development through outdoor recreation and tourism (Jarvis, 2000). Traditionally located in peripheral areas, national parks can represent unique tourist attractions (Bushell and Eagles, 2007; Wall Reinius and Fredman, 2007) and may therefore serve as rare engines of economic development in otherwise often weak regional economies by attracting spending from outside the region.

In Germany, the primary legal mandate of national parks is to protect endemic species and ecological integrity on large-scale ter-

\footnotetext{
* Corresponding author. Tel.: +49 93131 85428; fax: +49 9313185544. E-mail addresses: marius.mayer@uni-wuerzburg.de (M. Mayer), martin@martin-muller.net (M. Müller), manuel.woltering@uni-wuerzburg.de (M. Woltering), julius.arnegger@uni-wuerzburg.de (J. Arnegger), hubert.job@uni-wuerzburg.de (H. Job).

1 http://www.human.geographie.uni-wuerzburg.de/personen/.

2 http://www.martin-muller.net/.
}

ritories of mostly pristine character. As long as this mission is not compromised, national parks are open to scientific research, environmental education and to the experience of nature for the general public (German Federal Nature Conservation Act BNatSchG, 2002, $\S 24)$. Beyond this legal priority of protection, however, the designation of national parks more often than not also follows political rationales of attracting tourism to peripheral regions and promoting regional development. This regional development mission is reflected in the founding charters of ten of the existing 14 national parks in Germany. The designation of Eifel National Park in 2004, for example, explicitly addressed "the regional development of the local economy and of sustainable tourism in accordance with the conservation mission of the national park" as a primary goal (MUNVL, 2003, p. 2).

Economic benefits resulting from national park tourism offer a potential compensation to the local population, who has to bear the majority of indirect costs resulting from land use restrictions associated with the protection status of a particular area. Local opposition is a common feature in designations of new national parks, particularly in densely populated areas in Europe (Buijs, 2009; Liebecke et al., 2008; Stoll-Kleemann, 2001). This opposition occurs notwithstanding the amenity benefits for local communities such as easy access to pristine nature via bike paths and hiking trails for the purpose of recreation, improved environmental quality and scenic beauty. Economic benefits accruing from national park tourism, while highly dependent on tourists' disposable income, 
may facilitate the conservation mission by demonstrating the value of parks for people's livelihoods.

The potential economic effects have brought national parks into the focus of policy makers and social scientists alike. The significant scholarly and political interest notwithstanding, comparatively few quantifications of the economic impact of national parks exist. "Worldwide," Eagles et al. (2000, p. 62) state, "there is a low emphasis placed on the collection, compilation, and distribution of coordinated park-use data". Particularly in Germany, the majority of studies in this field fail to provide comprehensive primary data, probably because the free access policy in German national parks makes it difficult and costly to gauge visitor numbers and draw representative visitor samples. The present study is the first attempt to estimate the economic impact of tourism in a sample of six of the fourteen German national parks, based on a comprehensive survey of visitors. In particular, we were interested in visitor numbers, the structure and size of tourist expenditure and the economic impact of tourist expenditure.

\section{Research design}

\subsection{Methods}

We follow Watson et al. (2007) in defining economic impact as the net changes in new economic activity associated with a national park. In general, studies of economic impact model the recursive effects on income, output and employment caused by the injection of cash into an economy by a new activity. The initial round of expenditure triggers subsequent rounds, which create indirect effects of the initial cash injection in supplying businesses. Input-output models are currently the most common method for economic impact studies of tourism. They incorporate the sectoral interdependencies in an economy and allow disaggregating the economic impact of tourist expenditure across sectors (Fletcher, 1989; McDonald and Wilks, 1986). As an improvement to input-output models, several authors (e.g. Dwyer et al., 2004) have proposed computable general equilibrium (CGE) models which are able to include resource constraints and feedback effects.

Both input-output and CGE models require data about the sectoral supply linkages between firms. Unlike the IMPLAN system in the US, for example (e.g. Bonn and Harrington, 2008; Hjerpe and Kim, 2007), these data are not available at the sub-national level in Germany and many other European countries (see, e.g. Huhtala, 2007). It is generally possible to construct the models entirely from survey data (e.g. Walpole and Goodwin, 2000) or from a mix of survey and secondary data as so-called hybrid input-output models (cf. Lahr, 1993), but this becomes prohibitively costly if it has to be done in several different regions with thousands of businesses as in our case.

In view of the limited practicability of the above models for our study, we draw on the Keynesian multiplier approach instead (see Archer, 1977; Archer and Fletcher, 1996; Armstrong and Taylor, 2000 for reviews and critiques). The most common type of Keynesian multipliers is the income multiplier which is a measurement of the "amount of income generated in the economy concerned by an additional unit of tourist expenditure" (Archer, 1984, p. 517), i.e. tourism expenditure minus leakage (Hjerpe and Kim, 2007, p. 145). Regional income here is not equal to the gross regional product, since, in accordance with the system of national accounts, it only includes salaries and wages paid as well as income from operations and investment but not depreciation or subsidies.

The significantly reduced empirical costs to calculate this multiplier from secondary sources have contributed to its widespread use in studies of the economic impact of tourism at the local and regional level in several European countries (e.g. Berwert et al.,
2002; Küpfer and Elsasser, 2000; Metzler and Job, 2007; Rütter et al., 1995).

While capital investment into tourism infrastructure such as hotels, restaurants, shops or visitor centres is also part of the economic impact of tourism in national parks, in line with the majority of similar studies we consider only expenditure by tourists in this paper. Tourist expenditure, however, provides the income with which a sizable portion of capital investment is funded. We calculate the annual economic impact, denoted as $I$, of tourism in national parks in the following steps:

(1) Gross tourist spending $R^{g}$

$$
R^{g}=V \sum_{s=1}^{k} e_{s}
$$

where $V$ is the total number of visitor days per year, $e$ is the mean daily expenditure per visitor and $s$ denotes the different sectors of the economy $(1,2, \ldots, k)$.

(2) Net tourist spending $R^{n}$

$$
R^{n}=\sum_{s=1}^{k}\left(R_{s}^{g}-V A T_{s} V e_{s}\right)
$$

where $V A T_{S}$ is the value-added tax applicable to a particular economic sector.

(3) Direct regional income (from tourism spending) $I^{d}$

$$
I^{d}=\sum_{s=1}^{k}\left(R_{s}^{n} m_{s}^{d}\right)
$$

where $m_{s}^{d}$ is the direct multiplier for sector $s$, i.e. the proportion of income generated in a sector in the first round of the cash injection.

(4) Indirect regional income (from tourism spending) $I^{i}$

$I^{i}=\sum_{s=1}^{k}\left(R_{s}^{n}-I_{s}^{d}\right) m^{i}$

where $m^{i}$ is a flat indirect multiplier, equal for all sectors, i.e. the proportion of income generated in the second round of the cash injection.

(5) Total regional income (from tourism spending) I

$I=I^{d}+I^{i}$

If we substitute through the equations above we get

$I=\sum_{s=1}^{k} V e_{s}\left(1-V A T_{s}\right)\left[m_{s}^{d}+m^{i}\left(1-m_{s}^{d}\right)\right]$

The total income multiplier $m$ for a particular region then derives as

$m=\sum_{s=1}^{k}\left(1-V A T_{s}\right)\left[m_{s}^{d}+m^{i}\left(1-m_{s}^{d}\right)\right]$

Substituting with the above terms we get:

$I=\sum V e_{s} m$

In order to account for the considerable interregional differences in per capita income in Germany, we adjust the total regional income from tourism with the regional average income per capita in a final step to calculate income equivalents. In the absence of any job multiplier, this step calculates a hypothetical number of people who would be able to live off the income from 
tourist expenditure (including, for example, children and pensioners without any job). The number of jobs would be lower than the number of income equivalents, since the income from just one job often supports more than one person.

(6) Total income equivalents $I E$

$$
I E=\frac{I}{R I^{c}}
$$

where $R I^{c}$ denotes the regional average income per capita.

This method calculates the economic impact of all tourist expenditure in the national park regardless of whether it is motivated by the presence of the national park or not. In order to determine the unique economic impact of a national park, i.e. to account only for the tourist expenditure created in addition to the expenditure that would have occurred in the region anyway (cf. Loomis and Caughlan, 2006), we have to adjust the above values with the share of visitors with high national park affinity $a$ for whom the national park was the primary reason to come to the region (Wall Reinius and Fredman, 2007).

\subsection{Data collection and extrapolation}

In order to compute the economic impact of tourism in national parks according to the above method the following variables need to be obtained:

- the total number of visitor days per year $V$,

- the mean daily expenditure per visitor by economic sector $e_{s}$,

- the direct and indirect multipliers $m$ for different sectors,

- the regional average income per capita $R I^{c}$ and

- the share of visitors with high national park affinity $a$.

Multipliers $m$ were acquired from the Deutsches Wirtschaftswissenschaftliches Institut für Fremdenverkehr (dwif), a private consultancy collecting long-term economic data on tourism and tourism businesses in Germany, including inter-firm linkages. This consultancy conducts and syntheses primary surveys of internal cost structures and regional supply linkages of firms within the accommodation, catering, retail and transport sectors (dwif, 2007) which allows to calculate direct and indirect income multipliers. $m_{s}^{d}$ was available for different sectors of the economy in different regions, while $m^{i}$ was estimated to be an average of 30\% across all sectors based on studies on cost structures and business linkages. $R I^{c}$ for different regions are available from the state offices for statistics (Statistische Ämter des Bundes und der Länder, 2007).

Data for the remaining variables were collected through on-site visitor surveys in the six national parks in 2004 and 2007. In total 78,064 face-to-face interviews were conducted of which 67,586 were short interviews in which only the duration of the stay, visitor type (day-tripper vs. overnight visitor) and the type of accommodation as the most important determinants of tourist expenditure (Fredman, 2008; Kastenholz, 2005) were recorded. The remaining 10,478 long interviews focused on the structure and size of tourist expenditure by economic sectors and the affinity with the national park. When surveying tour groups, expenditure data was collected for only one person in the group, but the number and age of all group members were logged.

The share of visitors with high national park affinity $a$ in every national park was defined as the percentage of visitors that answered affirmatively to the three successive questions in Fig. 1.

Census points were selected in cooperation with national park management to coincide with the main access points to the national parks so as to record park visitation. In every national park, 20 census days were chosen to reflect variations in visitation by season, day of the week and weather conditions in order to obtain representative visitation data for the whole year (Niedersächsisches

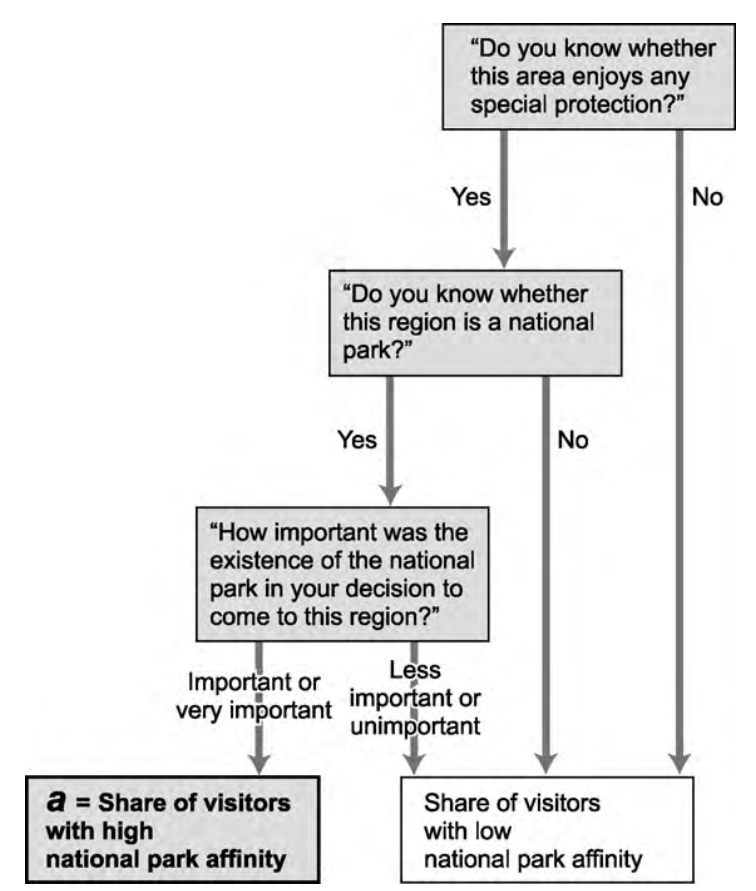

Fig. 1. Decision tree to determine visitors with high national park affinity.

Wattenmeer is an exception here, because reliable visitation figures could be obtained from the local authorities and official tourism statistics). The number of visitor days per year was extrapolated according to the formula below:

$V=\sum_{d=1}^{365} v \alpha_{d} \varepsilon_{d} \kappa_{d} \eta_{d}$

where $v$ is a constant and denotes the average visitor count obtained from the 20 census days. Subscript $d$ represents the days of the year and Greek letters represent variables: $\alpha$ is the adjustment factor to account for visitors outside the survey time on a census day. For every day of the year we calculate a seasonal adjustment factor $\varepsilon$ (high season/low season), a weather adjustment factor $\kappa$ (good weather/bad weather) and a day-of-the-week adjustment factor $\eta$ (weekday/weekend) from our census data. Weather data to calculate $\kappa$ were retrieved from the Deutscher Wetterdienst (DWD). When compared against visitor data from automated counting machines, which were available at some census points, deviations were found to be within a tolerable range of $10-15 \%$, thus validating our approach to gauge visitation figures (for a detailed exposition of the research design see, Job et al., 2009).

\section{Survey areas}

The six national parks in our sample range in size from 5724 ha (Kellerwald-Edersee) to 32,200 ha (Müritz)-or 277,700 ha if including the tidelands and water areas of Niedersächsisches Wattenmeer (see Fig. 2). All parks are listed as IUCN category II protected areas in the 2009 World Database on Protected Areas. Fig. 3 illustrates that the parks are either located in the outer periphery along the national border or in the inner periphery of the low mountain range in the sparsely populated former borderlands of the divided Germany. It is important to note that the six parks represent different stages and trajectories of development as a tourist destination (see Job, 2008; Job et al., 2009).

Niedersächsisches Wattenmeer has long been an established holiday destination, even before the national park was created in 1986, and is currently one of the most important tourist destinations in 


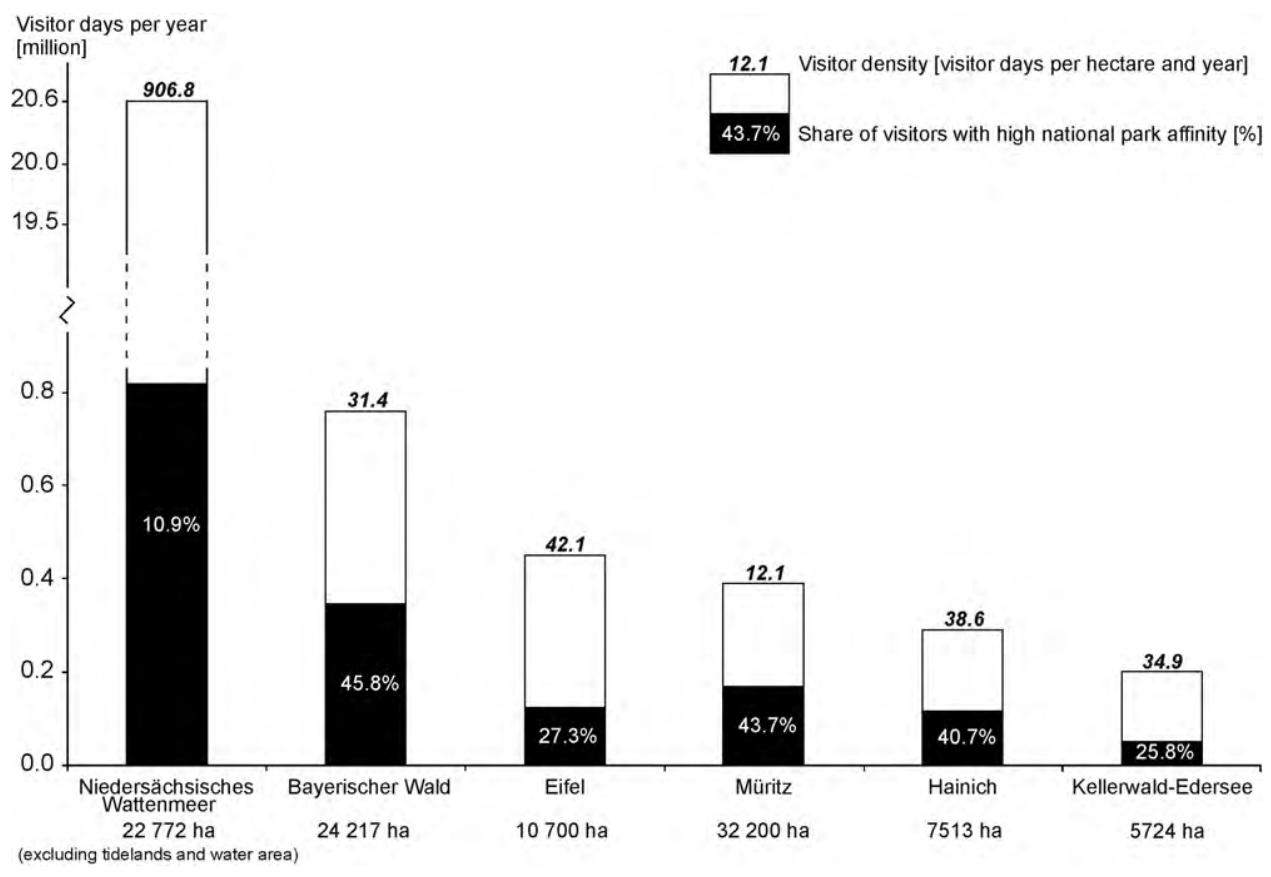

Fig. 2. Total visitor days, share of visitor days with high national park affinity and visitor density.

Germany (Beckmann, 2003). Covering an extensive part of the German North Sea shoreline, including six populated islands, visitors have flocked to the beaches and health resorts on the coast since the rapid development of spa tourism at the end of the 18th century (Kulinat, 1969). The designation as a national park thus occurred in the mature stage of Butler's tourism area lifecycle model (Butler, 1980). This explains why the national park plays a minor role in the tourism marketing of the region and cooperation between the national park and the tourism industry remains at a low level (Job et al., 2009).

In contrast, when Bayerischer Wald was designated in 1970 as the first national park in Germany, its primary mission was to stimulate tourism development in an economically depressed region adjacent to the Iron Curtain, which had acquired notoriety as the "poorhouse of the nation" (Haug, 1993). In the first two decades of the park's existence, the area experienced a rapid rise in inbound tourism, putting the region on the domestic tourist map. Although the tourism boom has petered out since the mid-1990s, the national park still serves as the primary attraction in the region and has made considerable efforts in creating relationships with tourism. At the same time, however, a regional bark beetle epidemic has been putting a strain on the public image of the national park since the mid-1990s as large swathes of the Norway spruce forest have turned into dead wood areas (Liebecke et al., 2008; Flint et al., 2009).

Established in 2004, Eifel is among the most recent national park designations in Germany and was established for the conservation of endemic beech forests. Unlike all other national parks, it is situated close to major agglomerations such as Cologne, Bonn, Aachen (in Germany) and Maastricht (in the Netherlands). This proximity taps a large market base of visitors, since it makes for easy access for day trips. Notwithstanding its short history, Eifel occupies an important place in regional tourism marketing and is actively promoted in a cooperation between national park management and tourism organisations (Job et al., 2009).

Müritz is situated in a structurally weak and sparsely populated lake district in East Germany. The designation of the national park in 1990 coincided with the start of market-based tourism. The label 'national park', it was hoped, would provide a competitive edge in marketing the destination for nature tourism and give a stimulus to the regional economy. Since then, tourist arrivals have indeed increased significantly and the park continues to be the main attraction in the region (Leibenath, 2007; Job, 2008).

Covering 7513 ha, Hainich is one of the smaller German national parks and protects the largest area of contiguous deciduous woodland in Germany. It is situated in the west of the state of Thuringia, in the former border zone between West and East Germany. National park management has been active in trying to develop this depressed region. Designated in 1997 in an area with rudimentary tourist infrastructure, the park has since built numerous hiking trails and opened a highly popular tree-top walk. It cooperates closely with actors from the tourism business and since the park is the only major point of attraction in the region, it features prominently in regional marketing campaigns (Job et al., 2009).

Kellerwald-Edersee, together with Eifel, is the youngest of German national parks. Designated in 2004, it covers an area of only 5724 ha comprising predominantly beech forests. The national park is close to the spa town of Bad Wildungen and includes the popular Edersee lake. Although the tourist potential of the national park has been recognised by regional tourist organisations and the national park management, up to now attempts to leverage the national park for nature tourism have remained few and far between (Job et al., 2009).

\section{Results}

\subsection{Visitation and national park affinity}

With a total of more than 20 million visitor days in 2007 Niedersächsisches Wattenmeer received almost 10 times more visits than the rest of the sample combined and more than 30 times more than Bayerischer Wald as the immediate runner-up (Fig. 2). National park affinity, however, was lowest in Niedersächsisches Wattenmeer, reaching only $10.9 \%$, whereas Bayerischer Wald at $45.8 \%$ was at the high end of the scale, closely followed by Müritz (43.7\%) and Hainich (40.7\%).

At more than 900 visitor days per hectare and year, visitor density is also considerably higher in Niedersächsisches Wattenmeer than in any of the other reserves. It surpasses the value of Müritz, 


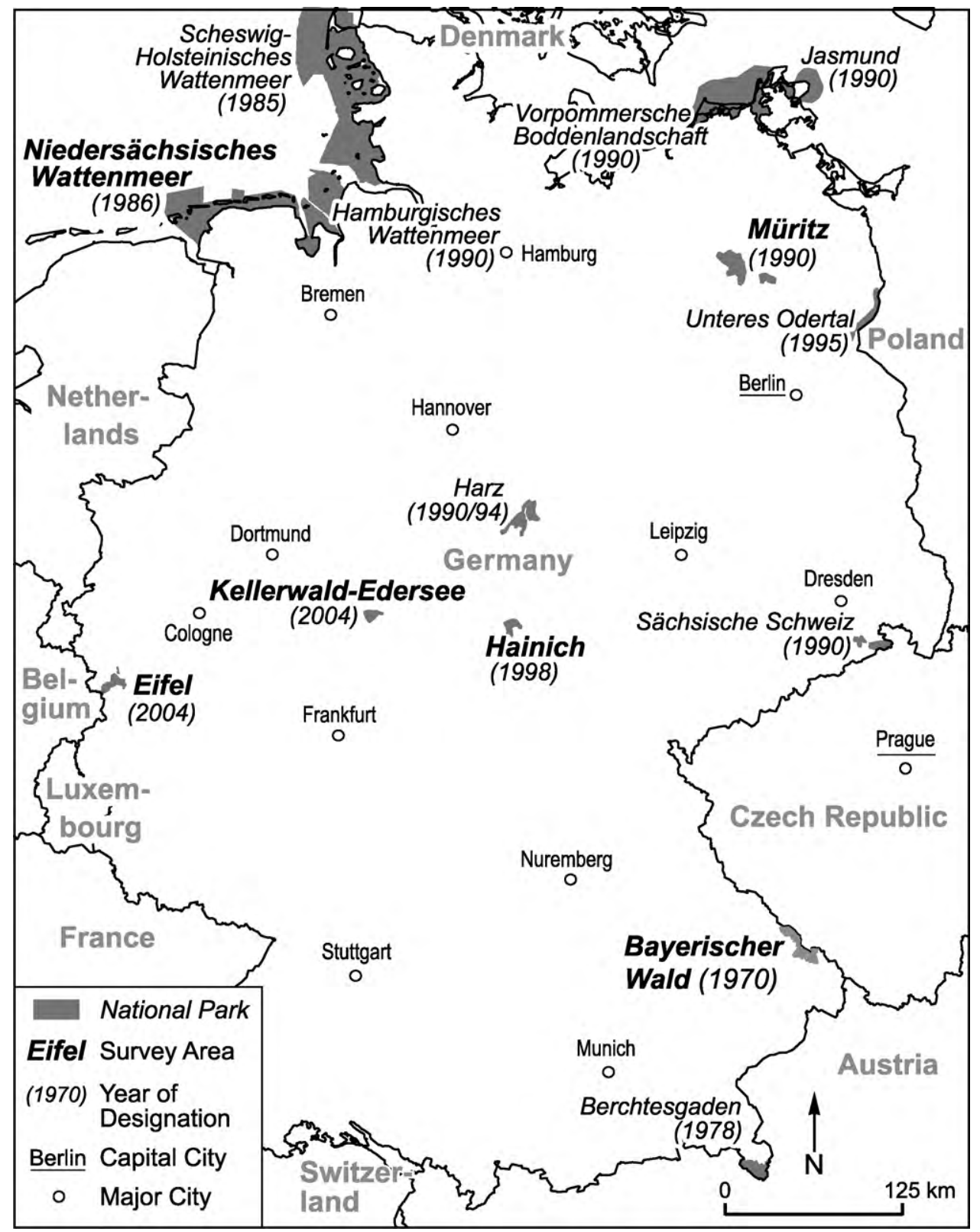

Fig. 3. Map of national parks in Germany.

the reserve with the lowest visitor density, by a magnitude of 75 . The other four reserves receive between 30 and 45 visitor days per hectare and year.

\subsection{Visitor characteristics}

Table 1 shows that the share of men and women visiting the national parks in our sample is more or less equal across all parks. The mean age of visitors differs significantly between most parks: Bayerischer Wald and Kellerwald-Edersee receive the youngest visitors $(M=40.5$ and $M=40.2)$, whereas Eifel has the oldest visitors at a mean age of 47.6. Mean group size ranges between 2.4 persons per party in Eifel and 2.8 persons in Hainich. The most frequent group size is two persons, which accounts for between $36.4 \%$ (KellerwaldEdersee) and 62.6\% (Müritz) of visitors.

There are marked differences in the split between day-trippers and overnight visitors in different national parks. More than $85 \%$ of visitor days in Niedersächsisches Wattenmeer can be attributed to overnight visitors, whereas the same figure stands at only $24 \%$ for
Eifel and Hainich. In general, overnight visitors mostly prefer private lodgings such as holiday apartments. Only in Eifel and Hainich does the share of visitors staying in hotels exceed the share of visitors staying in private lodgings. Staying overnight with friends or relatives is not uncommon. In Hainich more than $30 \%$ of all visitors stay with friends or relatives. Camping is also popular as an accommodation option, especially in Müritz where it reaches a proportion of $18.1 \%$.

\subsection{Structure of expenditure}

Table 2 illustrates that spending for accommodation and catering is roughly similar in size and makes up the largest parts of the budget for overnight visitors. Expenditure for accommodation varies between $45.8 \%$ of the total budget in Müritz and 36.6\% in Bayerischer Wald. The share of expenditure for catering services ranges from $42.7 \%$ for Eifel and $32.4 \%$ for Müritz. With a mean daily expenditure of EUR 56.87 for overnight visitors and EUR 12.83 for day-trippers, visitors were most generous in Niedersächsisches Wat- 

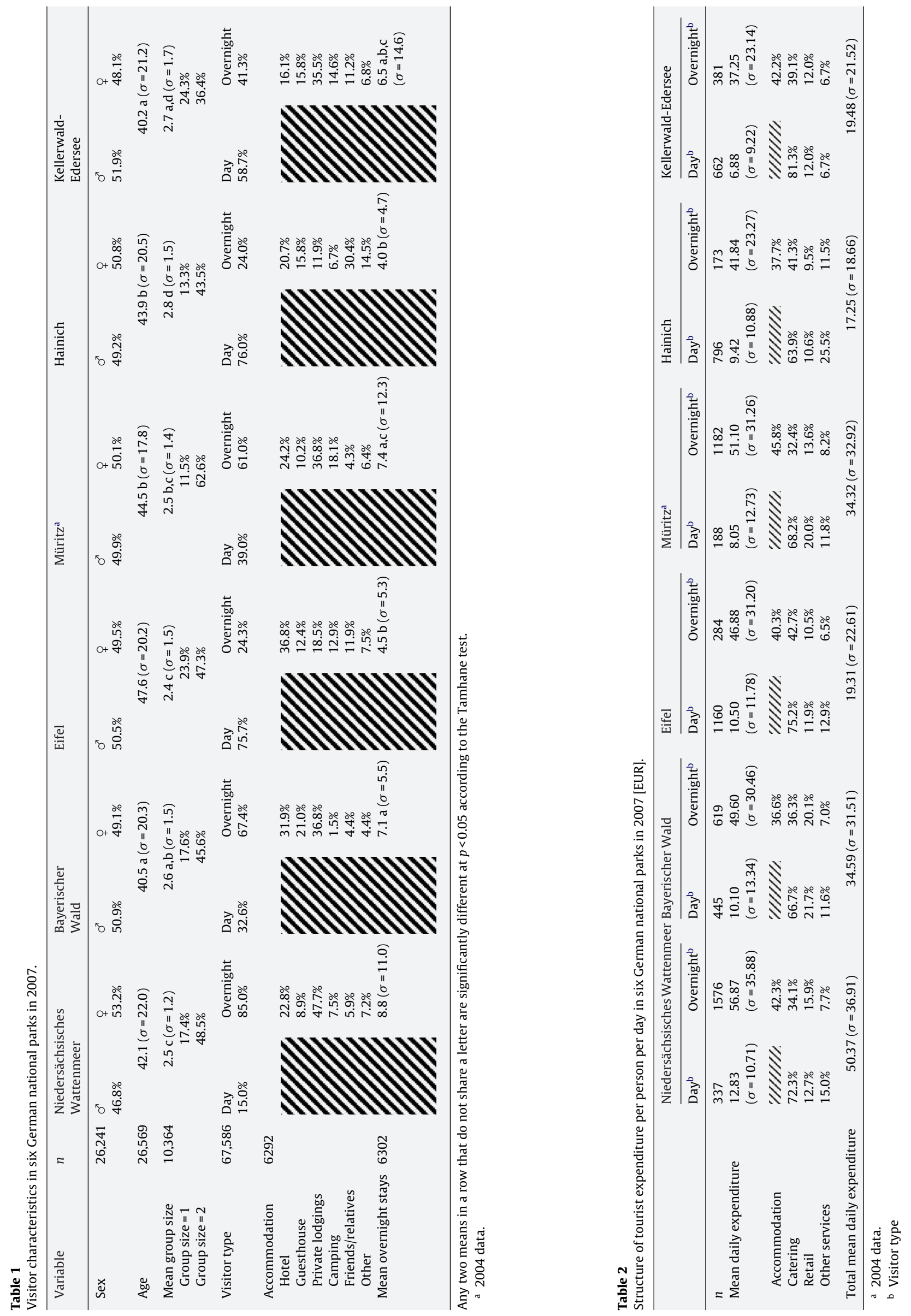
Table 3

Mean daily expenditure of overnight visitors per day by accommodation type [EUR].

\begin{tabular}{|c|c|c|c|c|c|c|c|c|c|c|c|c|}
\hline \multirow[b]{2}{*}{$n$} & \multicolumn{2}{|c|}{$\begin{array}{l}\text { Niedersächsisches } \\
\text { Wattenmeer }\end{array}$} & \multicolumn{2}{|c|}{ Bayerischer Wald } & \multicolumn{2}{|l|}{ Eifel } & \multicolumn{2}{|l|}{ Müritz* } & \multicolumn{2}{|l|}{ Hainich } & \multicolumn{2}{|c|}{ Kellerwald-Edersee } \\
\hline & 1576 & & 619 & & 284 & & 1182 & & 173 & & 381 & \\
\hline & $M$ & $\sigma$ & $M$ & $\sigma$ & $M$ & $\sigma$ & $M$ & $\sigma$ & $M$ & $\sigma$ & $M$ & $\sigma$ \\
\hline Hotel & 87.43 & 38.11 & 64.82 & 34.48 & $61.42 \mathrm{a}$ & 33.38 & 72.73 & 34.62 & $56.03 \mathrm{a}$ & 25.11 & 65.01 & 24.98 \\
\hline Guesthouse & 61.19 & 27.91 & $50.77 a$ & 24.35 & 46.88 a,b & 24.68 & 54.41 & 21.70 & $54.00 \mathrm{a}$ & 16.11 & 48.74 & 19.06 \\
\hline Private lodgings & 49.56 & 28.03 & $41.10 \mathrm{~b}$ & 25.86 & 37.74 b,c & 19.03 & $47.21 \mathrm{a}$ & 23.96 & 37.72 b,d & 15.57 & $31.58 \mathrm{a}$ & 13.30 \\
\hline Camping & $25.56 \mathrm{a}$ & 16.85 & 31.71 a,b,c & 20.56 & $28.60 \mathrm{c}, \mathrm{d}$ & 18.01 & 30.21 b,c & 21.67 & 27.08 b,c,d & 23.65 & $21.60 \mathrm{~b}, \mathrm{c}$ & 12.10 \\
\hline Friends/relatives & $30.09 a$ & 18.91 & 22.62 c & 18.74 & $29.45 \mathrm{~b}, \mathrm{~d}$ & 39.36 & 20.90 c & 17.22 & $16.23 \mathrm{c}$ & 12.18 & $15.73 \mathrm{~b}$ & 13.81 \\
\hline Other & $35.83 \mathrm{a}$ & 28.48 & 28.76 b,c & 21.54 & 39.19 b,d & 17.68 & $40.00 \mathrm{a}, \mathrm{b}$ & 28.81 & $36.02 \mathrm{~d}$ & 10.09 & $32.82 \mathrm{a}, \mathrm{c}$ & 20.88 \\
\hline Mean daily expenditure & 56.87 & 35.88 & 49.60 & 30.46 & 46.88 & 31.20 & 51.10 & 31.26 & 41.84 & 23.27 & 37.25 & 23.15 \\
\hline
\end{tabular}

Any two means in a column that do not share a letter are significantly different at $p<0.05$ according to the Tamhane test. 2004 data.

tenmeer, whereas Kellerwald-Edersee received the thriftiest visitors spending an average of EUR 6.88 on a day trip and EUR 37.25 if staying overnight. A sizable proportion of day-trippers do not spend any money at all: in Müritz 46.0\% of day-trippers do not have any expenditure, compared to a rather low share of $18.3 \%$ in Niedersächsisches Wattenmeer.

With the notable exceptions of day-trippers in Eifel (ANOVA, $F=6.33, p<0.05$ ) and overnight visitors in Müritz (ANOVA, $F=10.00$, $p<0.01$ ) there was no significant difference between the expenditures of visitors with high national park affinity and normal visitors if we distinguished between day-trippers and overnight visitors. In Bayerischer Wald and Eifel, however, visitors with high national park affinity were significantly more likely to be overnight visitors (Bayerischer Wald: Cramér's $V=0.088, p<0.01$; Eifel: Cramér's $V=0.087$, $p<0.001)$ and therefore had a higher overall expenditure. Due to the high proportion of overnight visitors Niedersächsisches Wattenmeer also had the highest mean daily expenditure across visitor types with EUR 50.37 per visit. In contrast, Hainich received the lowest expenditure with only EUR 17.25 per visit.

Visitors' overall expenditure differed significantly by accommodation type for most parks (Table 3). With the exception of Eifel and Hainich, hotel guests' expenditure was significantly higher than that of visitors choosing other accommodation. Hotel guests spent between 30\% (Bayerischer Wald) and 74\% (Kellerwald-Edersee) more than the average visitor. In contrast, the mean daily expenditure of visitors staying with friends and relatives was lowest and between $37 \%$ (Eifel) and 61\% (Hainich) below that of the average visitor.

\subsection{Economic impact}

Table 4 gives an overview of the estimated economic impact of the national parks in our sample. Niedersächsisches Wattenmeer took a clear lead with more than EUR 500 million created through tourism in the park, of which almost EUR 60 million are created by visitors with high national park affinity. Due to their higher share of overnight visitors, Bayerischer Wald and Müritz also performed reasonably well with EUR 13.5 million and EUR 6.9 million, respectively, for all visitors and EUR 6.5 million and EUR 2.8 million for those with high affinity. With a total regional income of less than EUR 5 million each, the remaining three national parks lagged behind.

Between $32 \%$ and $35 \%$ of gross visitor spending is retained as direct regional income in all national parks. Another $16 \%$, on average, is converted into indirect regional income. This translates into an income multiplier of between $49 \%$ and $51 \%$. About half of the gross tourist revenue is thus converted into regional income. The regional income retained from tourism in all national parks in our sample corresponds to a total of 32,432 IE (2143 without Niedersächsisches Wattenmeer). If we consider visitors with high national park affinity only, this figure decreases to 4282 IE (922 without Niedersächsisches Wattenmeer).

\section{Discussion}

\subsection{Explaining differences in visitation and national park affinity}

Differences in visitor density and national park affinity can be attributed to the parks' differing development and position in the tourist destination market. Being an established tourist destination, Niedersächsisches Wattenmeer attracts visitors regardless of the presence of the national park. The minor significance of the national park for generating additional visitor influx is reflected in the low proportion of visitors with high national park affinity. Bayerischer Wald, by contrast, is a much stronger tourist attraction and, in relative terms, contributes more to the economic development of the region, as is evidenced in the sizable share of visitors with high affinity.

It appears obvious that younger national parks like KellerwaldEdersee and Eifel, both of which were founded in 2004, still have generally low affinity rates due to their very recent designation and it can be expected that these rates will increase over the course of the next decade or two. The case of Hainich, however, proves that achieving high affinity ratings does not necessarily take decades. With a proportion of $40.7 \%$ of visitors with high affinity, Hainich demonstrates that the label "national park" can represent a key asset in the marketing and development of the destination from the very beginning. The designation of a national park alone, however, is not a panacea for attracting visitors. Despite its much longer history, Bayerischer Wald, for example, does not score much higher in the affinity rating than Hainich. This may be explained partly by a lack of acceptance and identification and, consequently, a lack of promotion and support by local stakeholders, especially tourism businesses (Mayer and Woltering, 2008). More generally, this suggests that a laissez-faire approach is not suitable for developing national parks as attractive labels for tourism marketing.

Comparing affinity rates from our study to national parks in other countries, the Swiss National Park turns out to have a rather large proportion of $42 \%$ of visitors with high affinity (Küpfer, 2000, p. 101). Yet, these rates are still low in comparison to national parks in the United States. Stynes $(2006,2007,2008)$ reports that for at least $75 \%$ of visitors surveyed in a number of US national parks the presence of the reserve is the primary reason to visit the region. National parks like Yellowstone even achieve rates above $90 \%$. It is important to realise, however, that the role of national parks as primary nuclei of touristic attraction (Leiper, 1990 ) is more salient in the US, where national parks are often the only major attraction in the region, than in most densely populated areas in Western Europe where national parks are just one of many other attractions. German national parks, for example, have, until recently, not been promoted as must-see attractions in the mass media or in guidebooks (Wall Reinius and Fredman, 2007). 


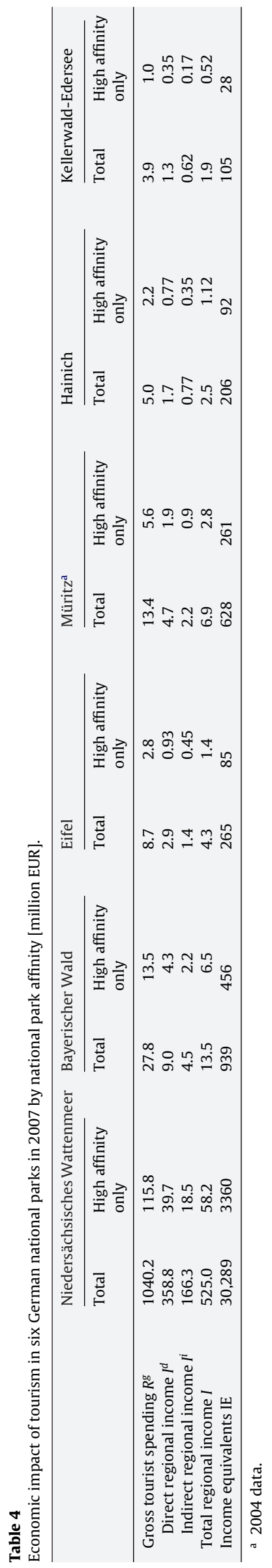

\subsection{Explaining differences in trip characteristics and expenditure structure}

The varying split between overnight and day visitors between national parks is probably related to two main factors. First, national parks receiving a high share of day-trippers are usually located in the proximity of urban agglomerations, whereas national parks receiving a high share of overnight visitors, such as Müritz or Bayerischer Wald, are usually in more peripheral locations where day trips from the urban agglomerations are inconvenient. Second, more mature holiday destinations seem to attract a higher share of overnight visitors. This is the case with Niedersächsisches Wattenmeer and, again, with Bayerischer Wald, whereas destinations in the earlier stages of the tourist lifecycle such as Hainich attract more day visitors, often by way of special attractions or events such as adventure walks.

The mean daily expenditure of national park visitors in our sample is significantly below the national averages for tourists in Germany. The average day-tripper in Germany spends EUR 28 per day; the average overnight tourist spends EUR 131.60 in commercial accommodation (hotels, guesthouses) and EUR 72.40 in non-commercial accommodation (private lodgings, camping) (dwif, 2002; Harrer and Scherr, 2010). The downward deviation in our sample is primarily linked to reduced possibilities and a low propensity for consumption in national parks as compared to cities, where shopping tourism is prevalent. The majority of national park visitors want to enjoy nature's beauty and expenditure in retail is therefore often limited to food and souvenirs.

Accommodation choice and tourism infrastructure also play an important role in determining the size of expenditure. Visitors in our sample prefer camping or other cheaper accommodation options such as private lodgings, which are often more appropriate for activities like hiking, canoeing and so on. Upscale accommodation, at the same time, is frequently unavailable or considerably less expensive than in urban areas. The most important gateway community in Hainich, for instance, does not even offer hotel accommodation. What is more, the sometimes sizable proportion of visitors who take advantage of staying with friends or relatives also lowers the mean expenditure significantly.

A preference for simple accommodation such as private lodgings, as it is the case in Niedersächsisches Wattenmeer for example, is not necessarily reflected in a low daily expenditure however. Quite to the contrary, Niedersächsisches Wattenmeer has the highest daily expenditure among overnight visitors. This points to the conclusion that different price levels across regions also play an important role in determining the size of expenditure.

Expenditure of overnight tourists in our sample is somewhat below that of other national parks in Europe. Visitors of the Swiss National Park had a mean daily expenditure of EUR 59.44 (Küpfer, 2000, p. 107f, inflated to 2007 values for comparison), spending more on accommodation (52\%), while spending considerably less on catering (21\%). Berghäll (2005, p. 64) found for the Archipelago National Park (Finland) a similar overnight expenditure of EUR 58.39 , where $46 \%$ went into catering but only $11.2 \%$ into accommodation.

\subsection{Economic impact}

Direct and indirect regional income from tourism in other national parks in Europe is in about the same magnitude as in our study. Küpfer (2000, inflated) reports EUR 10.6 million for the Swiss National Park, Huhtala (2007) EUR 12.1 million for the PallasOunastunturi National Park in Finland and Berghäll (2005) EUR 3.3 million for the Archipelago National Park in Finland. This is in the order of regional income from tourism in Bayerischer Wald and Hainich, respectively. 
If compared to national parks in the United States, however, the economic impact of tourism in German national parks is comparatively small. Direct regional income from Yellowstone and Yosemite national parks, for instance, is estimated at EUR 136 million and EUR 134 million, respectively, while even less popular parks like Joshua Tree derive a direct regional income from tourism of about EUR 12 million (Stynes, 2006, 2007). Unlike in Germany, parks in the US charge an entrance fee, are more geared towards motorised tourism, have a higher proportion of international visitors and often feature a wider range of consumption opportunities for memorabilia and other merchandise. The difference in the economic impact, however, is mainly due to the higher visitation, underscoring the salient position of national parks in the tourist attraction system of the United States as compared to Germany.

A sensitivity analysis shows that the economic impact reacts significantly more sensitively to changes in visitation than it does to changes in the multiplier. A variation of $10 \%$ in the total number of visitor days produces, ceteris paribus, a variation of $10 \%$ in the total regional income, because visitor days enter the equation as a simple factor. A $10 \%$ variation in visitor days is a common scenario in national parks, considering the fluctuations due to weather conditions or the general economic situation. To produce the same effect of variation in regional income, the direct multiplier, however, would have to vary by more than $20 \%$. This would imply a massive change in firms' cost structures, tax rates or supply linkages in the regional economy-a highly unlikely event.

\section{Conclusion}

This study has been the first to present a comprehensive dataset on the economic impact of tourism in German national parks. In our sample, the size of the economic impact changes primarily due to variation in the total visitor days and the mean daily expenditure of national park tourists. This suggests two main avenues for regional policy makers to increase the economic leverage of national parks: the first is quantitative upgrading by attracting more visitors, which could lead to additional ecological stress in already heavily frequented parks. The second option is qualitative upgrading by inducing visitors to increase expenditure. Qualitative upgrading could include measures to increase the share of overnight visitors, particularly in hotels and guesthouses, and to enhance the quality and, thus, increase the price of services. It is this second avenue of qualitative upgrading which contributes to an ecologically responsible tourism while at the same time creating jobs and entrepreneurial income in local communities. In addition, regional economic policy could also aim at increasing linkages between businesses and creating a strong supply base, thereby increasing the income multiplier. Promoting regional products in catering or the regional arts and crafts sector as a supplier for the souvenir business would keep money within the regional economy.

The generally low proportion of visitors with high national park affinity leaves ample room for improving the position of national parks on the tourist market and promoting their truly unique selling proposition of pristine wilderness. The launch of the common brand name "Nationale Naturlandschaften" and a coordinated marketing campaign for German protected areas in 2005 was a first step in this direction. Because visitors with high national park affinity stay longer and therefore spend more money, this kind of visitor marketing is also a promising avenue for increasing the total economic impact of tourism in German national parks.

Improved visitor marketing has to be accompanied by improved visitor monitoring. This must include a systematic and continuous survey of use levels and of the economic impact of tourism in national parks. Constructing computable general equilibrium (CGE) models for individual parks, albeit costly, would allow making more precise claims about the economic impact than the methodology used in our study. As Eagles et al. (2000, pp. 62-63) claim, it is politically dangerous not to have a monitoring system: "senior politicians, government policy-makers, and business planners make decisions based upon the available information. Those sectors with weak or incomplete information risk being undervalued when policy, planning, and management decisions are made."

\section{Acknowledgements}

This research project was funded by the German Federal Ministry for the Environment, Nature Conservation and Nuclear Safety under the UFO-Plan numbers 80387030 and 80682 030. Parts of the field work were funded by the respective National Park authorities. We would like to thank Daniel Metzler for his substantial contributions to preliminary phases of the project as well as the four anonymous reviewers for their insightful comments and remarks on this paper.

\section{References}

Archer, B., 1977. Tourism Multipliers: The State of the Art. University of Wales Press, Bangor, UK.

Archer, B., 1984. Economic impact: misleading multiplier. Ann. Tourism Res. 11 (3), 517-518.

Archer, B., Fletcher, J.E., 1996. The economic impact of tourism in the Seychelles. Ann. Tourism Res. 23 (1), 32-47.

Armstrong, H., Taylor, J., 2000. Regional Economics and Policy. Blackwell, Oxford, UK.

Beckmann, O., 2003. Die Akzeptanz des Nationalparks Niedersächsisches Watten meer bei der einheimischen Bevölkerung. (The Acceptance of Niedersächsisches Wattenmeer National Park Among the Local Population), Peter Lang, Frankfurt a. Main, Germany, (in German),

Berghäll, J., 2005. Saaristomeren kansallispuiston luontomatkailun aluetaloudel liset vaikutukset. (The Economic Impact of Ecotourism in Archipelago National Park, Finland), Metsähallituksen luonnonsuojelujulkaisuja, Vantaa, Finland (in Finnish).

Berwert, A., Rütter, H., Müller, H., 2002. Volkswirtschaftliche Bedeutung des Tourismus im Kanton Wallis (The economic significance of tourism in the Canton of Valais). DISP 149 (2), 4-12 (in German).

BNatSchG (Bundesnaturschutzgesetz, Gesetz über Naturschutz und Landschaftspflege), 2002. German Federal Law on Nature Conservation. Neufassung vom 25. März. Bundesgesetzblatt I: 1193 (in German).

Bonn, M.A., Harrington, J., 2008. A comparison of three economic impact models for applied hospitality and tourism research. Tourism Econ. 14 (4), 769-789.

Buijs, A.E., 2009. Public support for river restoration. A mixed-method study into local residents' support for and framing of river management and ecological restoration in the Dutch floodplains. J. Environ. Manage. 90 (8), 2680-2689, doi:10.1016/j.jenvman.2009.02.006.

Bushell, R., Eagles, P.F.J. (Eds.), 2007. Tourism and Protected Areas. Benefits Beyond Boundaries. CABI, Wallingford and Cambridge, UK.

Butler, R.W., 1980. The concept of a tourist area lifecycle of evolution: implications for management of resources. Can. Geogr. 24 (1), 5-12.

dwif (Deutsches Wirtschaftswissenschaftliches Institut für Fremdenverkehr) (Ed.), 2002. Ausgaben der Übernachtungsgäste in Deutschland. (Expenditure of Overnight Guests in Germany). Author, Munich, Germany, (in German).

dwif (Deutsches Wirtschaftswissenschaftliches Institut für Fremdenverkehr) (Ed.), 2007. Betriebsvergleich für die Hotellerie und Gastronomie in Bayern. (Comparison of Accommodation and Gastronomy Businesses in Bavaria). Author, Munich, Germany, (in German).

Dwyer, L., Forsyth, P., Spurr, R., 2004. Evaluating tourism's economic effects: new and old approaches. Tourism Manage. 25 (3), 307-317, doi:10.1016/S02615177(03)00131-6.

Eagles, P.F.J., McLean, D., Stabler, M.J., 2000. Estimating the tourism volume and value in parks and protected areas in Canada and the USA. George Wright Forum 17 (3), 62-82.

Fletcher, J.E., 1989. Input-output analysis and tourism impact studies. Ann. Tourism Res. 16, 514-529.

Flint, C.G., McFarlane, B.L., Müller, M., 2009. Human dimensions of forest disturbance by insects: an international synthesis. Environ. Manage. 43 (6), 1174-1186, doi:10.1007/s00267-008-9193-4.

Fredman, P., 2008. Determinants of visitor expenditures in mountain tourism. Tourism Econ. 14 (2), 297-311.

Harrer, B., Scherr, S., 2010. Ausgaben der Übernachtungsgäste in Deutschland. (Expenditure of Overnight Guests in Germany), Author, Munich, Germany, (in German).

Haug, M., 1993. Entstehungsgeschichte des Nationalparks Bayerischer Wald und Entwicklung seit 1969 [A history of the foundation of Bavarian Forest National Park and its development since 1969]. In: Bayerisches Staatsministerium für Ernährung, Landwirtschaft und Forsten (Ed.), Eine Landschaft wird Nationalpark [A Landscape Turns into a National park]. Morsak-Verlag, Grafenau, Germany, pp. 35-84 (in German). 
Hjerpe, E.E., Kim, Y.-S., 2007. Regional economic impacts of Grand Canyon river runners. J. Environ. Manage. 85 (1), 137-149, doi:10.1016/j.jenvman.2006.08.012.

Huhtala, M., 2007. Assessment of the local economic impacts of national park tourism: the case of Pallas-Ounastunturi National Park. Forest Snow Landsc. Res. 81 (1/2), 223-238.

IUCN (World Conservation Union), 2008. Guidelines for Protected Areas Management Categories. Part II. The Management Categories. Author, Gland, Switzerland.

Jarvis, T.D., 2000. The responsibility of national parks in rural development. In Machlis, G.E., Field, D.R. (Eds.), National Parks and Rural Development: Practice and Policy in the United States. Island Press, Washington, DC, pp. 219230.

Job, H., 2008. Estimating the regional economic impact of tourism to national parks: two case studies from Germany. GAIA 17 (S1), 134-142.

Job, H., Woltering, M., Harrer, B., 2009. Regionalökonomische Effekte des Tourismus in deutschen Nationalparken. (The Regional Economic Impact of Tourism in German National Parks), Bundesamt für Naturschutz, Bonn-Bad Godesberg Germany, (in German).

Kastenholz, E., 2005. Analysing determinants of visitor spending for the rural tourist market in North Portugal. Tourism Econ. 11 (4), 555-569.

Kulinat, K., 1969. Geographische Untersuchungen über den Fremdenverkehr der niedersächsischen Küste. (Geographic Research on Tourism at the Lower-Saxon Coast), Wurm, Göttingen, Germany, (in German).

Küpfer, I., Elsasser, H., 2000. Regionale touristische Wertschöpfungsstudien: Fallbeispiel Nationalparktourismus in der Schweiz. (Regional value-added studies in tourism: the case of national park tourism in Switzerland). Tourismus J. 4 (4) 433-448 (in German).

Küpfer, I., 2000. Die regionalwirtschaftliche Bedeutung des Nationalparktourismus untersucht am Beispiel des Schweizerischen Nationalparks. (The Regional Economic Importance of National Park Tourism. The Example of the Swiss National Park), Forschungskommission des Schweizerischen Nationalparks, Zernez, Switzerland, (in German).

Lahr, M.L., 1993. A review of the literature supporting the hybrid approach to constructing regional input-output models. Econ. Syst. Anal. 5 (3), 277-293, doi:10.1080/09535319300000023.

Leibenath, M., 2007. Market-driven governance of biodiversity: an analysis of the Müritz National Park region (Germany) from a marketing perspective. In: Mose, I. (Ed.), Protected Areas and Regional Development in Europe. Ashgate, Aldershot, UK, pp. 161-178.

Leiper, N., 1990. Tourist attraction systems. Ann. Tourism Res. 17 (3), 367-384

Liebecke, R., Wagner, K., Suda, M., 2008. Nationalparks im Spannungsfeld zwischen Prozessschutz, traditionellen Werten und Tourismus - Das Beispiel Nationalpark Bayerischer Wald. (National parks between ecological integrity, traditional values and tourism-the example of Bayerischer Wald
National Park). Jahrbuch des Vereins zum Schutz der Bergwelt 73, 125-138 (in German).

Loomis, J., Caughlan, L., 2006. The importance of adjusting for trip purpose in regional economic analyses of tourist destinations. Tourism Econ. 12 (1), 33-43.

Mayer, M., Woltering, M., 2008. Angebotsseitige Analyse des Tourismus in der Nationalparkregion Bayerischer Wald (A supply-side analysis of tourism in the Bayerischer Wald National Park region). In: Job, H. (Ed.), Die Destination Nationalpark Bayerischer Wald als regionaler Wirtschaftsfaktor (The Destination Bayerischer Wald National Park as a Regional Economic Asset). Nationalparkverwaltung Bayerischer Wald, Grafenau, Germany, pp. 66-99 (in German).

McDonald, G.T., Wilks, L.C., 1986. The regional economic impact of tourism and recreation in national parks. Environ. Plann. B 13 (3), 349-366.

Metzler, D., Job, H., 2007. Events und ihr Beitrag zur Regionalökonomie: die BUGA 05 (Events and their impact on the regional economy: the BUGA 05). Raumforschung und Raumordnung 65 (6), 514-530 (in German).

MUNVL (Ministerium für Umwelt und Naturschutz, Landwirtschaft und Verbraucherschutz des Landes Nordrhein-Westfalen), 2003. Verordnung über den Nationalpark Eifel in der Fassung der Bekanntmachung vom 17. Dezember 2005 [Eifel National Park Act published on December 17, 2005]. Author, Düsseldorf, Germany (in German).

Rütter, H., Müller, H., Guhl, D., Stettler, J., 1995. Tourismus im Kanton Bern: Wertschöpfungsstudie. (Tourism in the Canton of Berne: A Value-added Study) Universität Bern, Bern, Switzerland, (in German).

Statistische Ämter des Bundes und der Länder (Eds.), 2007. Einkommen der privaten Haushalte in den kreisfreien Städten und Landkreisen Deutschlands 1995 bis 2006 [Income of Private Households in German Cities and Counties from 1995 to 2006]. Author, Düsseldorf, Germany. (in German), electronic resource retrieved on April 7, 2010 from http://www.tls.thueringen.de/ public/pdf/2006/60204_2006_01.XLS.

Stoll-Kleemann, S., 2001. Opposition to the designation of protected areas in Germany. J. Environ. Plann. Man. 44 (1), 109-128, doi:10.1080/09640560123606.

Stynes, D.J., 2006. Impacts of Visitor Spending on the Local Economy: Joshua Tree National Park, 2004. Michigan State University, East Lansing, MI.

Stynes, D.J., 2007. Impacts of Visitor Spending on the Local Economy: Yosemite National Park, 2005. Michigan State University, East Lansing, MI.

Stynes, D.J., 2008. Impacts of Visitor Spending on the Local Economy: Zion National Park, 2006. Michigan State University, East Lansing, MI.

Wall Reinius, S., Fredman, P., 2007. Protected areas as attractions. Ann. Tourism Res. 34 (4), 839-854, doi:10.1016/j.annals.2007.03.011.

Walpole, M.J., Goodwin, H.J., 2000. Local economic impacts of dragon tourism in Indonesia. Ann. Tourism Res. 27 (3), 559-576.

Watson, P., Wilson, J., Thilmany, D., Winter, S., 2007. Determining economic contributions and impacts: what is the difference and why do we care? J. Reg. Anal. Pol. 37 (2), 140-146. 